Article

\title{
Triphlorethol-A from Ecklonia cava Up-Regulates the Oxidant Sensitive 8-Oxoguanine DNA Glycosylase 1
}

\section{Ki Cheon Kim ${ }^{1}$, In Kyung Lee ${ }^{2}$, Kyoung Ah Kang ${ }^{1}$, Mei Jing Piao ${ }^{1}$, Min Ju Ryu ${ }^{3}$, Jeong Mi Kim ${ }^{4}$, Nam Ho Lee ${ }^{4}$ and Jin Won Hyun ${ }^{1, *}$}

1 School of Medicine, Jeju National University, Jeju 690-756, Korea;

E-Mails: svv771@hotmail.com (K.C.K.); legna07@naver.com (K.A.K.); meijing0219@hotmail.com (M.J.P.)

2 Radiation Effect Research Team, Radiation Health Research Institute, Korea Hydro \& Nuclear Power Co., LTD., Seoul 135-881, Korea; E-Mail: inkyeong@korea.ac.kr

3 Food and Nutrition, Duksung Women's University, Seoul 132-714, Korea;

E-Mail: rmj5924@naver.com

4 Department of Chemistry, College of Natural Sciences, Jeju National University, Jeju 690-756, Korea; E-Mails: jmkin1263@jejunu.ac.kr (J.M.K.); namho@jejunu.ac.kr (N.H.L.)

* Author to whom correspondence should be addressed; E-Mail: jinwonh@jejunu.ac.kr; Tel.: +82-64-754-3838; Fax: +82-64-702-2687.

External Editor: Peer B. Jacobson

Received: 10 July 2014; in revised form: 2 October 2014 / Accepted: 14 October 2014 / Published: 28 October 2014

Abstract: This study investigated the protective mechanisms of triphlorethol-A, isolated from Ecklonia cava, against oxidative stress-induced DNA base damage, especially 8-oxoguanine (8-oxoG), in Chinese hamster lung fibroblast V79-4 cells. 8-Oxoguanine DNA glycosylase-1 (OGG1) plays an important role in the removal of 8-oxoG during the cellular response to DNA base damage. Triphlorethol-A significantly decreased the levels of 8-oxoG induced by $\mathrm{H}_{2} \mathrm{O}_{2}$, and this correlated with increases in OGG1 mRNA and OGG1 protein levels. Furthermore, siOGG1-transfected cell attenuated the protective effect of triphlorethol-A against $\mathrm{H}_{2} \mathrm{O}_{2}$ treatment. Nuclear factor erythroid 2-related factor 2 ( $\mathrm{Nrf} 2$ ) is a transcription factor for OGG1, and Nrf2 combines with small Maf proteins in the nucleus to bind to antioxidant response elements (ARE) in the upstream promoter region of the OGG1 gene. Triphlorethol-A restored the expression of nuclear Nrf2, small Maf protein, and the Nrf2-Maf complex, all of which were reduced by oxidative stress. Furthermore, 
triphlorethol-A increased Nrf2 binding to ARE sequences and the resulting OGG1 promoter activity, both of which were also reduced by oxidative stress. The levels of the phosphorylated forms of Akt kinase, downstream of phosphatidylinositol 3-kinase (PI3K), and Erk, which are regulators of OGG1, were sharply decreased by oxidative stress, but these decreases were prevented by triphlorethol-A. Specific PI3K, Akt, and Erk inhibitors abolished the cytoprotective effects of triphlorethol-A, suggesting that OGG1 induction by triphlorethol-A involves the PI3K/Akt and Erk pathways. Taken together, these data indicate that by activating the DNA repair system, triphlorethol-A exerts protective effects against DNA base damage induced by oxidative stress.

Keywords: antioxidant response elements; 8-oxoguanine; Nrf2; OGG1; Triphlorethol-A

\section{Introduction}

Single bases within a DNA strand can be chemically damaged by deamination, oxidation, or alkylation through a variety of mechanisms [1]. Among the various types of DNA base damage caused by oxidative stress, 8-oxoguanine (8-oxoG) forms abundantly and easily [2,3]. 8-OxoG is formed by reaction of guanine with reactive oxygen species (ROS), and can induce DNA mutation or alteration. Ultimately, such changes can trigger apoptosis and diverse diseases, such as atherosclerosis, diabetes, Parkinson's disease, and various cancers [4-8]. Single-base lesions such as 8-oxoG are repaired by the base excision repair (BER) system [9], which recognizes and removes damaged and irrelevant bases [10]. A component of the BER system, 8-oxoguanine DNA glycosylase 1 (OGG1), repairs 8-oxoG via the BER pathway by cleaving the glycosidic bond of the 8-oxoG lesion and causing a strand break in the DNA backbone [11,12]. The OGG1 promoter region contains nuclear factor erythroid 2-related factor 2 (Nrf2)-binding sites, called antioxidant response elements (ARE) [13,14]. The transcription factor Nrf2 is essential for ARE-mediated induction of genes encoding phase-II detoxification and oxidative stress-response enzymes [15]. Nrf2 binds to the ARE with high affinity only as a heterodimer with a small Maf protein, suggesting that the Nrf2/small Maf complex activates gene expression directly through the ARE [16]. The small Maf proteins, Maf F, Maf G, and Maf K, contain leucine-zipper (Zip) domains that are required for homodimer or heterodimer complex formation with other Zip transcription factors [17]. To function as transcription factor, Nrf2 must dissociate from Keap1, which degrades Nrf2 by targeting it for ubiquitination, and translocate to the nucleus [15]. The phosphorylation of Nrf2 is the primary signal causing its dissociation from Keap1. The phosphoinositide 3-kinase (PI3K)/Akt pathway may also play an important role in the activation of Nrf2 $[18,19]$. In addition, Erk phosphorylation activates Nrf2 and induces its translocation to the nucleus [20].

Triphlorethol-A is a phlorotannin compound derived from the brown alga Ecklonia cava. Our recent study showed that triphlorethol-A increases heme oxygenase- 1 activity by elevating the transcriptional activity of Nrf2 [21], and also ameliorates the effects of formaldehyde on non-homologous end joining and BER capacity [22]. Furthermore, this compound enhances the activities of the antioxidant system and inhibits cellular damage against ultraviolet B rays, thereby protecting human keratinocytes against 
ultraviolet B radiation [23]. In light of these observations, our current study focused on the ability of triphlorethol-A to protect cells against $\mathrm{H}_{2} \mathrm{O}_{2}$-induced DNA base damage and investigated the molecular mechanisms underlying this protective effect.

\section{Results}

\subsection{Triphlorethol-A Suppresses $\mathrm{H}_{2} \mathrm{O}_{2}$-induced 8-oxoG Formation}

We previously reported that optimal dose of triphlorethol-A which protected V79-4 cells against oxidative stress was $30 \mu \mathrm{M}$ [24]. Therefore, $30 \mu \mathrm{M}$ of triphlorethol-A was used in these experiments. 8-OxoG is one of the critical forms of ROS-induced oxidative base lesions in DNA, and so has been widely used as a biomarker for oxidative stress and carcinogenesis [25]. We analyzed the 8-oxoG levels in DNA by ELISA assay using specific antibodies against 8-ohdG (a nucleoside of 8-oxoG). Levels of 8-oxoG were significantly higher in $\mathrm{H}_{2} \mathrm{O}_{2}$-treated cells than in control cells; however, triphlorethol-A treatment decreased the levels of 8-oxoG detected in $\mathrm{H}_{2} \mathrm{O}_{2}$-treated cells (Figure 1A). We also estimated the amount of 8-oxoG in a fluorescence-based binding assay using an avidin-conjugated TRITC reagent [26]. The fluorescence intensity generated by 8-oxoG was elevated in $\mathrm{H}_{2} \mathrm{O}_{2}$-treated cells; however, cells treated with $\mathrm{H}_{2} \mathrm{O}_{2}$ and triphlorethol-A exhibited a significantly lower fluorescence intensity (Figure 1B). These results suggest that triphlorethol-A decreases 8-oxoG levels in $\mathrm{H}_{2} \mathrm{O}_{2}$-treated cells.

\subsection{Triphlorethol-A Reverses the Suppression of OGG1 mRNA and Protein Expression by}

$\mathrm{H}_{2} \mathrm{O}_{2}$ Treatment

OGG1, a component of the BER system initiated by oxidation of DNA bases, is the primary enzyme responsible for the excision of the 8-oxoG lesion, a mutagenic base byproduct that occurs as a result of exposure to ROS [2]. To determine transcription levels of the OGG1 gene, we measured OGG1 mRNA expression using RT-PCR. Levels of OGG1 mRNA were lower in $\mathrm{H}_{2} \mathrm{O}_{2}$-treated cells than in control cells; however, triphlorethol-A treatment restored the levels of OGG1 mRNA in $\mathrm{H}_{2} \mathrm{O}_{2}$-treated cells to control levels (Figure 2A). Additionally, triphlorethol-A pretreatment significantly increased the levels of OGG1 protein in $\mathrm{H}_{2} \mathrm{O}_{2}$-treated cells compared with those in cells treated with $\mathrm{H}_{2} \mathrm{O}_{2}$ alone (Figure 2B). These data indicate that triphlorethol-A can reverse the reduction in OGG1 transcription and OGG1 protein expression by $\mathrm{H}_{2} \mathrm{O}_{2}$ treatment. Furthermore, cell viability was significantly increased in $\mathrm{H}_{2} \mathrm{O}_{2}$-treated cells treated with triphlorethol-A, compared to $\mathrm{H}_{2} \mathrm{O}_{2}$-treated cells (Figure 3). However, this cyto-protective effect of triphlorethol-A was attenuated in siOGG1-transfected cells, suggesting that OGG1 might involve in cell survival via DNA repair (Figure 3). 
Figure 1. Triphlorethol-A suppresses 8-oxoG generated by $\mathrm{H}_{2} \mathrm{O}_{2}$ treatment. (a) Cells were treated with $30 \mu \mathrm{M}$ triphlorethol-A for $1 \mathrm{~h}$, and then incubated with $1 \mathrm{mM} \mathrm{H} \mathrm{H}_{2} \mathrm{O}_{2}$ for an additional $24 \mathrm{~h}$. The amount of 8-oxoG in DNA was determined using the Bioxytech 8-OHdG-ELISA kit. * Significantly different from control cells $(p<0.05)$ and ** significantly different from $\mathrm{H}_{2} \mathrm{O}_{2}$-treated cells ( $p<0.05$ ); (b) The binding of avidin-TRITC, which reflects 8-oxoG levels, was visualized with a fluorescence microscope.

a

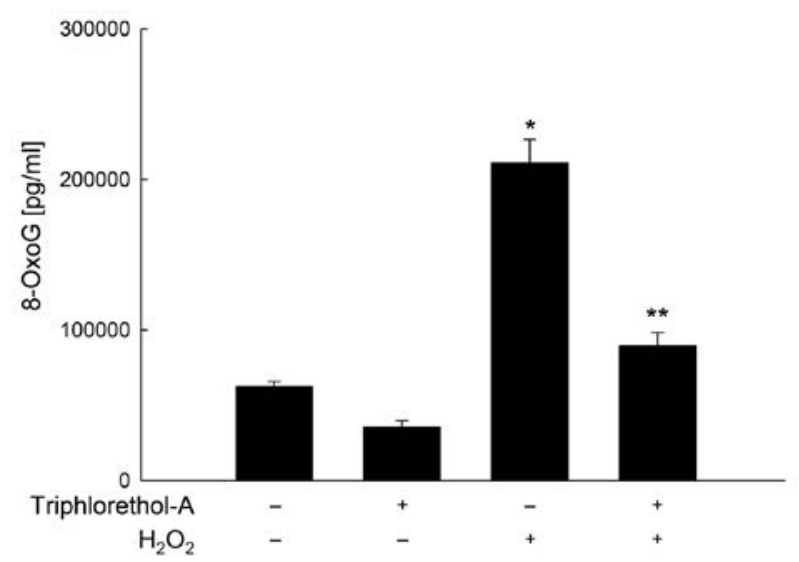

b
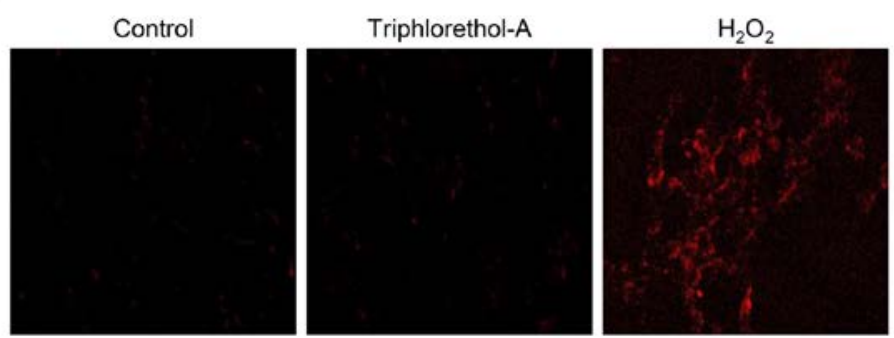

Triphlorethol- $\mathrm{A}+\mathrm{H}_{2} \mathrm{O}_{2}$

Figure 2. Triphlorethol-A induces OGG1 mRNA and OGG1 protein expression. (a) Cells were treated with $30 \mu \mathrm{M}$ triphlorethol-A for $1 \mathrm{~h}$, and then incubated with $1 \mathrm{mM} \mathrm{H}_{2} \mathrm{O}_{2}$ for an additional 24 h. OGG1 mRNA levels were detected by RT-PCR analysis; (b) OGG1 protein levels were detected by Western-blot analysis.

a

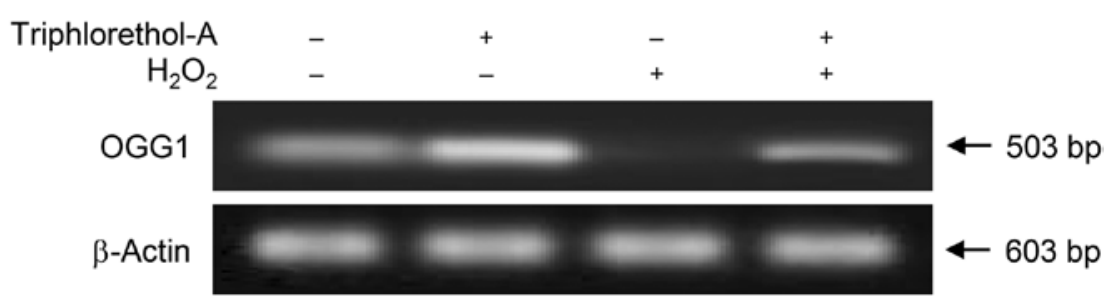

b

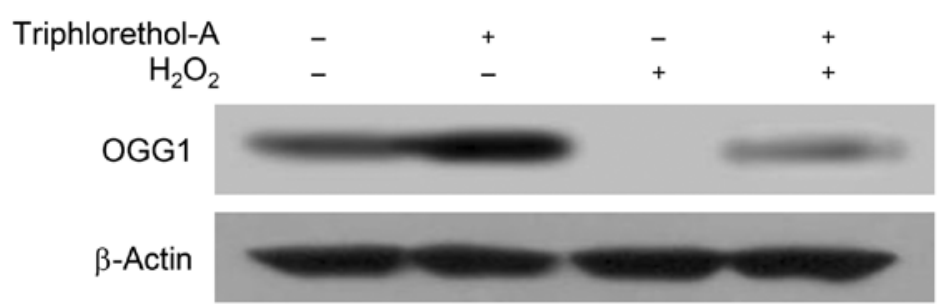


Figure 3. Down-regulation of OGG1 attenuates the cyto-protective effect of triphlorethol-A against $\mathrm{H}_{2} \mathrm{O}_{2}$-treated cells. The siRNA-transfected cells were treated with $30 \mu \mathrm{M}$ triphlorethol-A for $1 \mathrm{~h}$, and then incubated with $1 \mathrm{mM} \mathrm{H} \mathrm{H}_{2}$. After $24 \mathrm{~h}$, cell viability was assessed by the MTT assay. * Significantly different from siControl cells $(p<0.05)$; ** significantly different from $\mathrm{H}_{2} \mathrm{O}_{2}$-treated siControl cells $(p<0.05)$, and \# significantly different from siOGG1-transfected cells $(p<0.05)$.
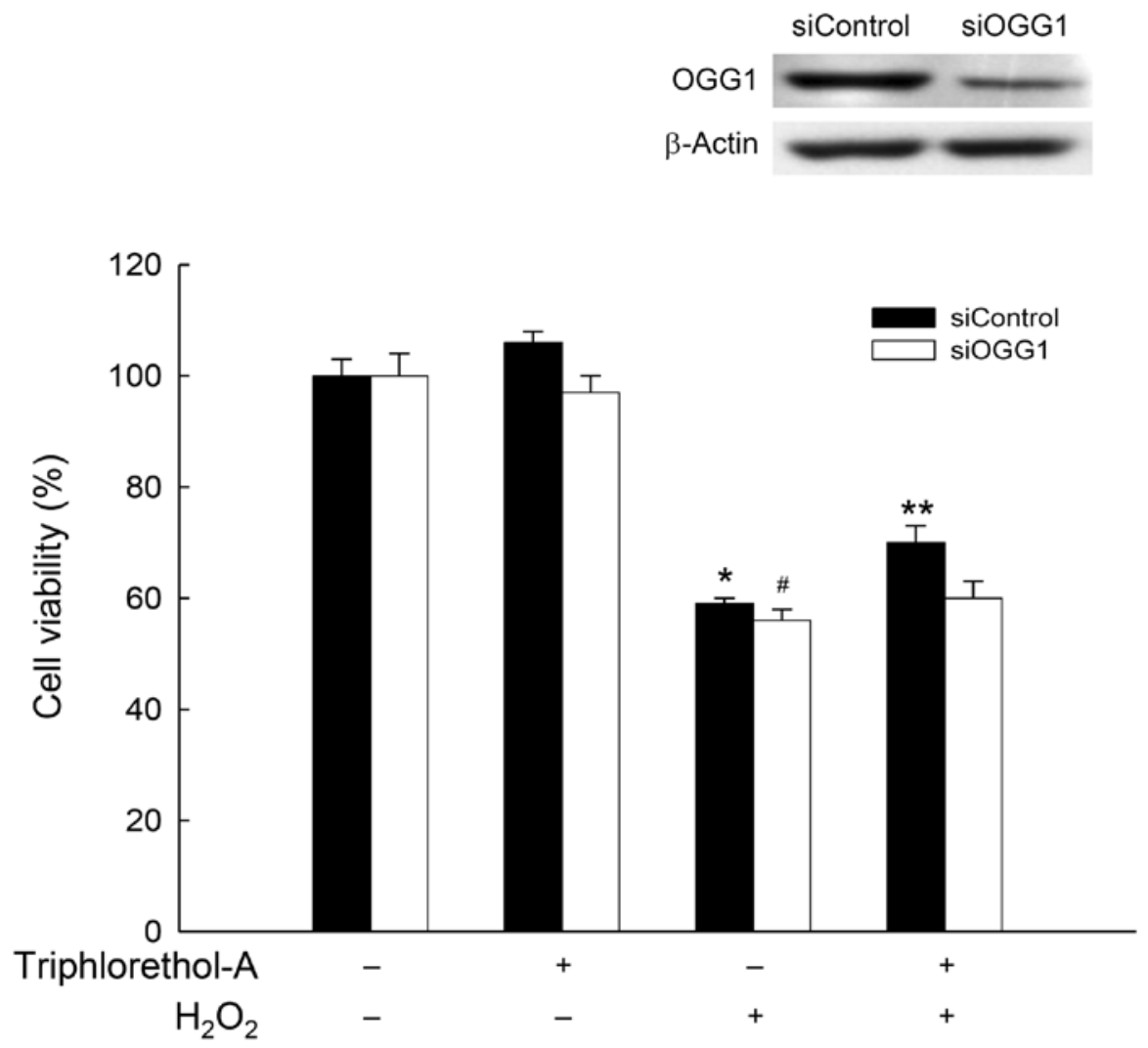

\subsection{Triphlorethol-A Blocks Inhibition of OGG1 Transcription by $\mathrm{H}_{2} \mathrm{O}_{2}$ Treatment}

The OGG1 promoter region contains transcription factor binding sites (ARE sequences) for Nrf2 [13,27]. Nrf2 binds to the ARE with a small Maf protein, and activates gene expression directly through the ARE [16]. To analyze the levels of Nrf2 and small Maf proteins in the nucleus, we extracted nuclear proteins and measured the expression of each protein by Western blotting. $\mathrm{H}_{2} \mathrm{O}_{2}$ treatment decreased the nuclear levels of Nrf2 and small Maf proteins; however, triphlorethol-A treatment restored these proteins to control levels (Figure 4A). To determine whether Nrf2 was bound to small Maf proteins in the nucleus, nuclear lysates were immunoprecipitated with an anti-Nrf2 antibody and subjected to Western blotting using an antibody against small Maf proteins. $\mathrm{H}_{2} \mathrm{O}_{2}$ treatment decreased the binding of Nrf2 to small Maf proteins, and triphlorethol-A treatment restored this binding (Figure 4B). Moreover, triphlorethol-A treatment prevented the suppression of Nrf2 binding to the ARE sequence following $\mathrm{H}_{2} \mathrm{O}_{2}$ treatment (Figure 4C). To measure the OGG1 promoter activity, we employed a luciferase reporter vector driven by the promoter region of OGG1. $\mathrm{H}_{2} \mathrm{O}_{2}$ treatment decreased the transcriptional activity of the OGG1 promoter; however, triphlorethol-A treatment restored the promoter activity to control levels (Figure 4D). Thus, in cells treated with $\mathrm{H}_{2} \mathrm{O}_{2}$, triphlorethol-A restored OGG1 expression via up-regulation of Nrf2 and activity of the OGG1 promoter. 
Figure 4. Triphlorethol-A induces expression of Nrf2 and small Maf protein, Nrf2-ARE binding and OGG1 promoter activity. (a) Cells were treated with $30 \mu \mathrm{M}$ triphlorethol-A for $1 \mathrm{~h}$, and then incubated with $1 \mathrm{mM} \mathrm{H}_{2} \mathrm{O}_{2}$ for an additional $12 \mathrm{~h}$. Nuclear extracts were electrophoresed, and nuclear Nrf2, small Maf proteins, and TATA box-binding protein (TBP) were detected using specific antibodies; (b) Nuclear extracts were immunoprecipitated with an anti-Nrf2 antibody and subjected to Western blotting using antibodies against small Maf protein (upper) or Nrf2 (lower); (c) EMSA was performed with probes containing the ARE sequence from the OGG1 regulatory region. Nuclear extracts were incubated with the probes, and the protein-DNA complexes and free probes were resolved by electrophoresis; (d) After overnight transfection with the OGG1 promoter luciferase vector, cells were treated with triphlorethol-A for $1 \mathrm{~h}$ and then incubated with $1 \mathrm{mM} \mathrm{H}_{2} \mathrm{O}_{2}$ for a further $12 \mathrm{~h}$. Cells were lysed and cell lysates were mixed with a luciferase substrate. Luciferase activity was measured with a luminometer. * Significantly different from control cells $(p<0.05)$, and $* *$ significantly different from $\mathrm{H}_{2} \mathrm{O}_{2}$-treated cells $(p<0.05)$.

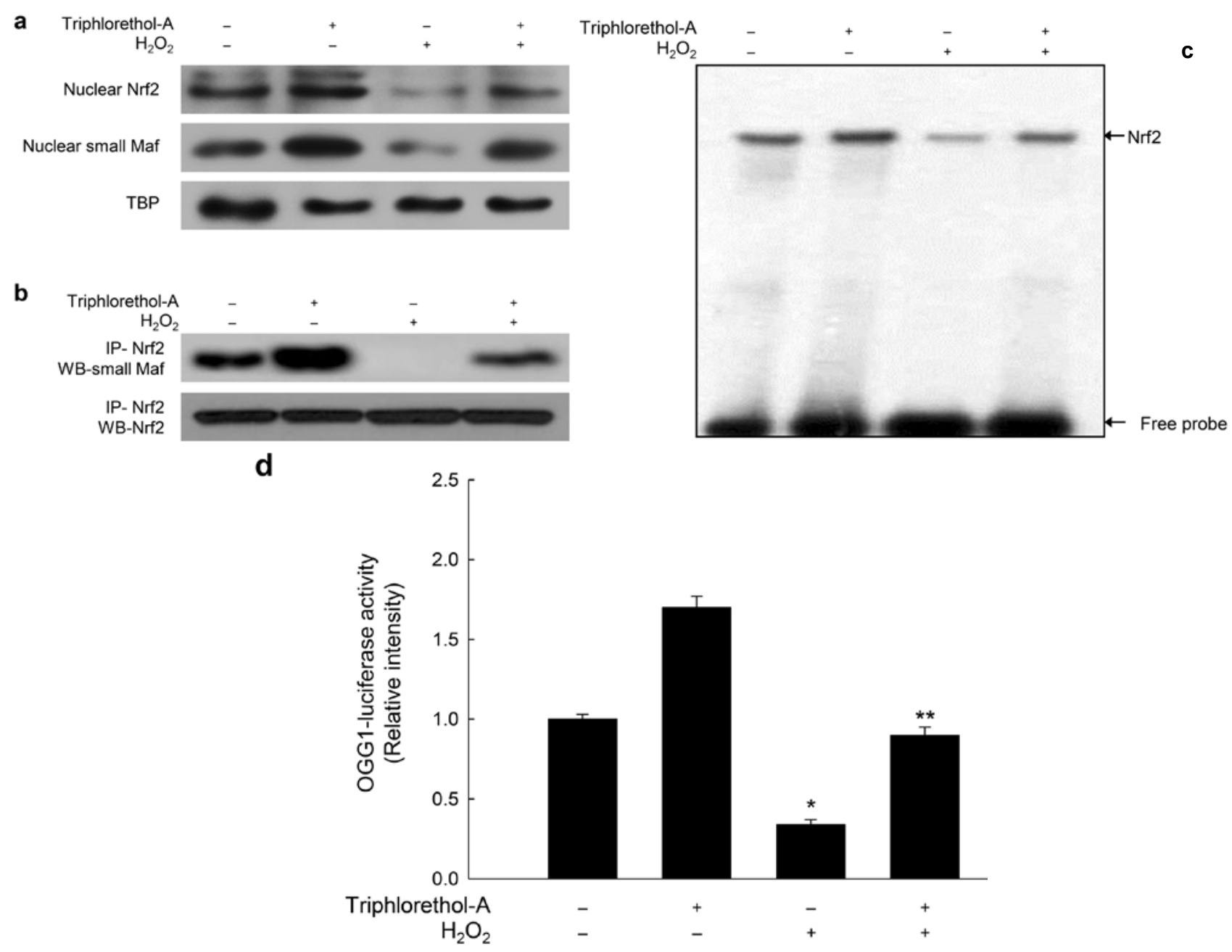


Figure 5. Triphlorethol-A induces OGG1 expression via signaling pathways and improves cell survival. (a) Cells were treated with $30 \mu \mathrm{M}$ triphlorethol-A for $1 \mathrm{~h}$, and then incubated with $1 \mathrm{mM} \mathrm{H} \mathrm{H}_{2}$ for a further $12 \mathrm{~h}$. Cell lysates were electrophoresed, and Akt and its phosphorylated form were detected using specific antibodies; (b) Cells were pretreated with $50 \mu \mathrm{M}$ LY294002 or $1 \mu \mathrm{M}$ Akt inhibitor IV for $1 \mathrm{~h}$, and then treated with $30 \mu \mathrm{M}$ triphlorethol-A for a further $24 \mathrm{~h}$. OGG1 was detected by Western blotting using an anti-OGG1 antibody; (c) Cells were pretreated with $50 \mu \mathrm{M}$ LY294002 or $1 \mu \mathrm{M}$ Akt inhibitor IV for $1 \mathrm{~h}$, then treated with $30 \mu \mathrm{M}$ triphlorethol-A for $1 \mathrm{~h}$, and then incubated with $1 \mathrm{mM}$ of $\mathrm{H}_{2} \mathrm{O}_{2}$ for a further $24 \mathrm{~h}$. Cell viability was assessed by the MTT assay. * Significantly different from control cells $(p<0.05)$, ** significantly different from $\mathrm{H}_{2} \mathrm{O}_{2}$-treated cells $(p<0.05)$, and $* * *$ significantly different from $\mathrm{H}_{2} \mathrm{O}_{2}$-treated cells also treated with triphlorethol-A ( $p<0.05$ ); (d) Cells were treated with $30 \mu \mathrm{M}$ triphlorethol-A for $1 \mathrm{~h}$, and were then treated with $1 \mathrm{mM} \mathrm{H}_{2} \mathrm{O}_{2}$ for a further $12 \mathrm{~h}$. Phosphorylated Erk expression was detected by Western blotting; (e) Cells were pretreated with $1 \mu \mathrm{M}$ U0126 for $1 \mathrm{~h}$, and then treated with $30 \mu \mathrm{M}$ triphlorethol-A for a further $24 \mathrm{~h}$. OGG1 expression was detected by Western blotting; (f) Cells were pretreated with $1 \mu \mathrm{M}$ U0126 for $1 \mathrm{~h}$, then treated with $30 \mu \mathrm{M}$ triphlorethol-A for $1 \mathrm{~h}$, and then incubated with $1 \mathrm{mM} \mathrm{H} \mathrm{H}_{2} \mathrm{O}_{2}$ for a further $24 \mathrm{~h}$. Cell viability was assessed by the MTT assay. * Significantly different from control cells $(p<0.05)$, ** significantly different from $\mathrm{H}_{2} \mathrm{O}_{2}$-treated cells $(p<0.05)$, and *** significantly different from $\mathrm{H}_{2} \mathrm{O}_{2}$-treated cells also treated with triphlorethol-A $(p<0.05)$.

a

Triphlorethol-A

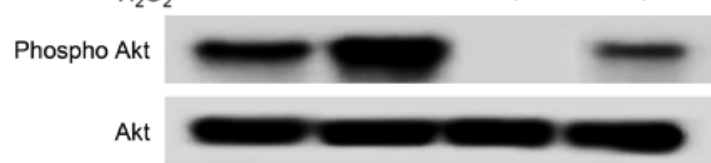

b

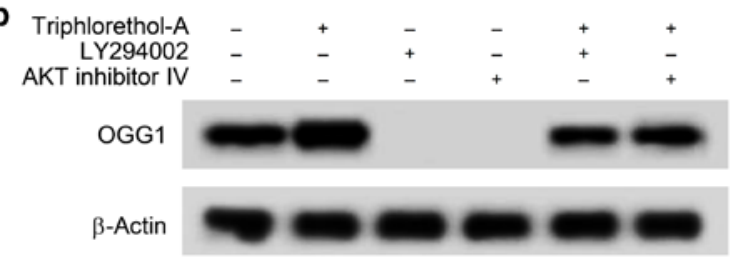

C

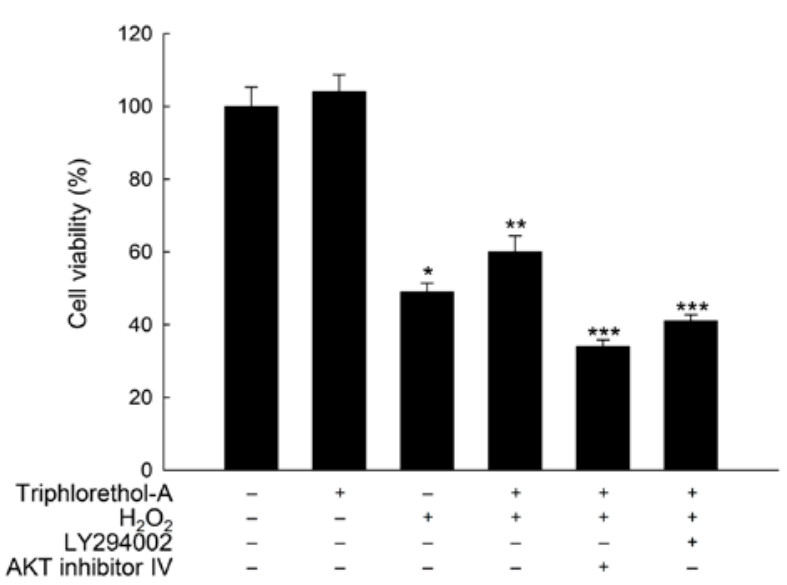

d

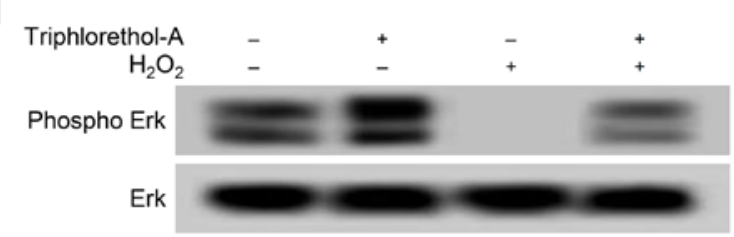

e

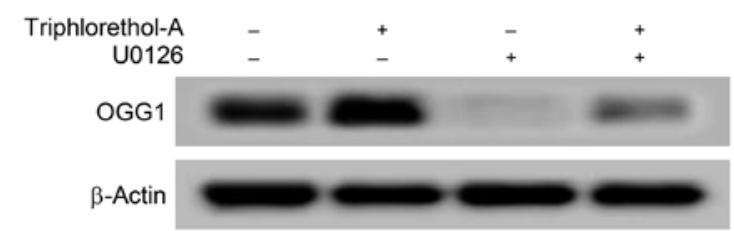

f

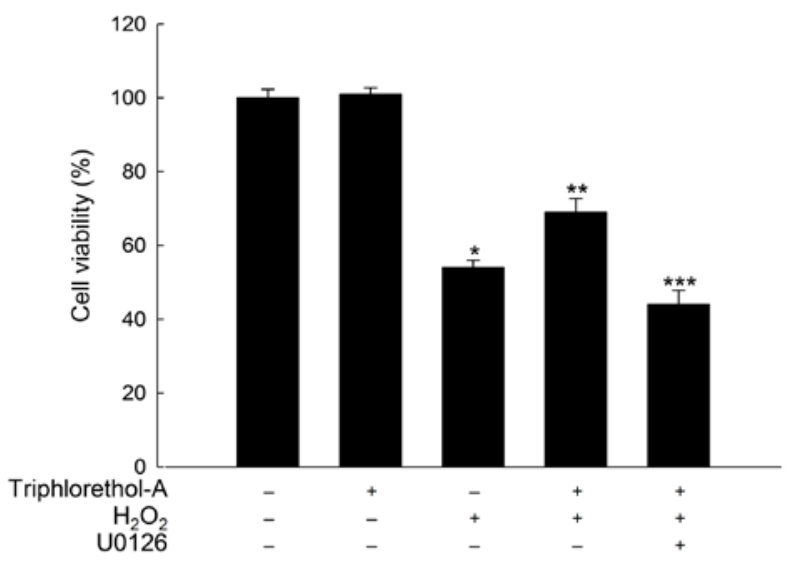




\subsection{Triphlorethol-A Induces OGG1 Expression via the PI3K/Akt and Erk Pathways}

The PI3K/Akt pathway is a major signaling process involved in cell survival during oxidative stress. Recently, it was reported that the promoter region contains Nrf2-binding sites, and that the PI3K/Akt pathway is involved in the up-regulation of OGG1 [14]. Akt activity, which correlates with Akt phosphorylation, was decreased upon $\mathrm{H}_{2} \mathrm{O}_{2}$ treatment, but triphlorethol-A treatment restored Akt activation to control levels (Figure 5A). Treatment with LY294002 (a PI3K inhibitor) or Akt inhibitor IV attenuated the ability of triphlorethol-A treatment to restore OGG1 expression (Figure 5B). Likewise, cell viability was inhibited by $\mathrm{H}_{2} \mathrm{O}_{2}$ treatment, but triphlorethol-A treatment partially restored viability to control levels; however, the restoration of cell viability by triphlorethol-A was blocked by treatment with PI3K and Akt inhibitors (Figure 5C). Phosphorylation of Nrf2 by Erk at conserved sites is required for release of Nrf2 from Keap1, and Erk phosphorylation is involved in Nrf2 nuclear translocation; in addition, direct phosphorylation of Nrf2 by Erk is required for Nrf2/DNA binding and subsequent transactivation [20]. Furthermore, under redox stress several effectors translocate Nrf2 from the cytoplasm to the nucleus in response to Erk-mediated Nrf2 phosphorylation at Ser40, and nuclear Nrf2 induces the transcription of the OGG1 gene [13,28]. Triphlorethol-A pretreatment of $\mathrm{H}_{2} \mathrm{O}_{2}$-treated cells restored the levels of phosphorylated Erk to control levels, whereas the level in cells treated with $\mathrm{H}_{2} \mathrm{O}_{2}$ alone was markedly reduced (Figure 5D). Treatment with U0126, an Erk inhibitor, suppressed the restoration of OGG1 expression by triphlorethol-A treatment in $\mathrm{H}_{2} \mathrm{O}_{2}$-treated cells (Figure 5E). Furthermore, U0126 abolished the protective effect of triphlorethol-A against $\mathrm{H}_{2} \mathrm{O}_{2}$-induced cell death (Figure 5F). These results indicate that the PI3K/Akt and Erk pathways partially regulate Nrf2 transcriptional activity and OGG1 expression, and thereby affect cell viability.

\section{Experimental Section}

\subsection{Reagents}

The plasmid containing the OGG1 promoter luciferase construct was a generous gift from Professor Ho Jin You (Chosun University, Gwangju, Korea). Avidin-conjugated tetramethylrhodamine isothiocyanate (TRITC), [3-(4,5-dimethylthiazol-2-yl)-2,5-diphenyltetrazolium] bromide (MTT), and an antibody against OGG1 were purchased from Sigma-Aldrich Corporation (St. Louis, MO, USA). Antibodies against Nrf2, small Maf, phospho-Akt, Akt, phospho-Erk, Erk, and $\beta$-actin were purchased from Santa Cruz Biotechnology (Santa Cruz, CA, USA). TATA box binding protein (TBP) antibody was purchased from Abcam (Cambridge, MA, USA). LY294002, Akt inhibitor IV and U0126 were purchased from Calbiochem (San Diego, CA, USA).

\subsection{Isolation of Triphlorethol-A}

The E. cava was dried in the shade and cut into small pieces. The dried sample $(2.0 \mathrm{~kg})$ was extracted with $80 \%$ aqueous methanol at room temperature for $24 \mathrm{~h}$. The combined solution was filtered, and the filtrate was concentrated under reduced pressure to afford the extract (259 g). The obtained extract was suspended on water, and partitioned into $n$-hexane (6.3 g) and ethyl acetate 
(30.8 g)-soluble fractions. The ethyl acetate fraction was subjected to column chromatography over celite by eluting successively with $n$-hexane, methylene chloride, diethyl ether and methanol to give four fractions. The third fraction (10.0 g) eluted with diethyl ether was purified by column chromatography with eluent of chloroform/methanol (2/1) to give 21 fractions (fr. 1-21). The fraction 14 (323.8 mg) was identified to be triphlorethol-A as determined by spectroscopic method including the analysis of magnetic resonance spectroscopy (NMR) spectra, and confirmed by the comparison of the data to the literature values [29].

\subsection{Cell Culture}

Chinese hamster lung fibroblasts (V79-4) were obtained from the American Type Culture Collection (Rockville, MD, USA) and cultured in Dulbecco's modified Eagle's medium containing $10 \%$ heat-inactivated fetal calf serum, streptomycin $(100 \mu \mathrm{g} / \mathrm{mL})$, and penicillin (100 Units/mL). Cells were maintained at $37^{\circ} \mathrm{C}$ in an incubator with a humidified atmosphere of $5 \% \mathrm{CO}_{2}$. The cell doubling time of V79-4 is approximately $12 \mathrm{~h}$, and cells were used for this study at $60 \%-70 \%$ confluence.

\subsection{Detection of $8-0 x o G$}

Cellular DNA was isolated using DNAzol reagent (Life Technologies, Grand Island, NY, USA) and quantified using a spectrophotometer. The amount of 8-hydroxy-2-deoxyguanosine (8-ohdG; a nucleoside of 8-oxoG) in the DNA was determined using the Bioxytech 8-OHdG ELISA kit from OXIS Health Products (Portland, OR, USA) according to the manufacturer's instructions. The detected 8-ohdG level was considered to represent the 8-oxoG level. The amount of 8-ohdG was also estimated using a fluorescence-based binding assay [26]. Avidin binds with high specificity to both 8-oxoG and 8-ohdG. Cells were fixed and permeabilized with ice-cold methanol for 15 min and incubated with avidin-conjugated TRITC (fluorescent dye) for $1 \mathrm{~h}$ at room temperature. 8-OxoG was visualized using a fluorescence microscope.

\subsection{Reverse Transcriptase-Polymerase Chain Reaction (RT-PCR)}

Total RNA was isolated from cells using easy-BLUE ${ }^{\mathrm{TM}}$ (iNtRON Biotechnology, Kyounggi, Korea). PCR conditions for OGG1 and the housekeeping gene $\beta$-actin were as follows: $94{ }^{\circ} \mathrm{C}$ for $2 \mathrm{~min}$; 35 cycles of $94{ }^{\circ} \mathrm{C}$ for $20 \mathrm{~s}, 58{ }^{\circ} \mathrm{C}$ for $30 \mathrm{~s}$, and $72{ }^{\circ} \mathrm{C}$ for $1 \mathrm{~min}$; and $72{ }^{\circ} \mathrm{C}$ for $5 \mathrm{~min}$. The primer pairs (Bioneer Corporation, Daejeon, Korea) were as follows: mouse OGG1, sense 5'-GCAGAGCCCTGCTCACTGGA-3' and antisense 5'-CGAGGATGGCTTTGGCACTG-3'; mouse $\beta$-actin, sense 5'-GTGGGCCGCCCTAGGCACCAGG-3' and antisense 5'-GGAGGAAGAGGA TGCGGCAGTG-3'. Amplified products were resolved by $1 \%$ agarose gel electrophoresis, stained with ethidium bromide, and photographed under ultraviolet light.

\subsection{Extraction of Total Cellular Proteins and a Nucleus Protein Fraction}

Cells were seeded in a plate at a concentration of $1 \times 10^{5}$ cells $/ \mathrm{mL}$. To extract total cellular proteins, cells were lysed on ice for $30 \mathrm{~min}$ in $150 \mu \mathrm{L}$ of PRO-PREPTM (iNtRON Biotechnology, Kyounggi, Korea) and centrifuged at 13,000 rpm for $30 \mathrm{~min}$. To extract nuclear proteins, cells were lysed using 
the Subcellular Protein Fractionation kit (Thermo Scientific, Milwaukee, WI, USA) according to the manufacturer's instructions.

\subsection{Western Blotting}

Cell or nuclear lysates were collected, and protein concentrations were determined using the Bradford reagent. Aliquots of the lysates ( $40 \mu \mathrm{g}$ of protein) were boiled for $5 \mathrm{~min}$ and electrophoresed on $10 \%$ SDS-polyacrylamide gels. Gels were transferred onto nitrocellulose membranes (Bio-Rad, Hercules, CA, USA). Membranes were then incubated with the indicated primary antibodies, and further incubated with secondary immunoglobulin G-horseradish peroxidase conjugates. Protein bands were visualized by developing the blots using an Enhanced Chemiluminescence (ECL) Western blotting detection kit (Amersham, Buckinghamshire, UK) and exposing the ECL-treated membranes to X-ray film.

\subsection{Immunoprecipitation}

Cell lysates were mixed with Nrf2 antibody and shaken at $4{ }^{\circ} \mathrm{C}$ overnight. Next, $30 \mu \mathrm{L}$ of protein $\mathrm{G}$-agarose beads were added to the lysates, and the mixture was shaken for $2 \mathrm{~h}$ at $4{ }^{\circ} \mathrm{C}$. The lysates were centrifuged at $6000 \mathrm{rpm}$ for $5 \mathrm{~min}$, and the protein G-agarose beads were collected. Collected beads were incubated with elution buffer for $30 \mathrm{~min}$ on ice, and then centrifuged at 13,000 rpm for 5 min. Supernatants were collected, and protein concentrations were determined using the Bradford reagent.

\subsection{Electrophoretic Mobility Shift Assay (EMSA)}

Oligonucleotides containing the Nrf2-binding domain (ARE sequence) were labeled with $\left[\gamma-{ }^{32} \mathrm{P}\right]$ ATP using T4 polynucleotide kinase, and the labeled oligonucleotides were used as probes. The probes (50,000 cpm) were incubated with the nuclear extracts at $4{ }^{\circ} \mathrm{C}$ for $30 \mathrm{~min}$ in a final volume of $20 \mu \mathrm{L}$ containing 12.5\% glycerol, $12.5 \mathrm{mM}$ HEPES (pH 7.9), 4 mM Tris-HCl (pH 7.9), $60 \mathrm{mM} \mathrm{KCl,} 1 \mathrm{mM}$ EDTA, $1 \mathrm{mM}$ DTT, and $1 \mu \mathrm{g}$ of poly $(\mathrm{dI}-\mathrm{dC})$. Binding products were resolved on $5 \%$ polyacrylamide gels, and the bands were visualized by autoradiography.

\subsection{Transient Transfection and OGG1-Promoter Luciferase Assay}

Cells were transiently transfected with a reporter plasmid harboring the OGG1 promoter using the transfection reagent DOTAP (Roche, Mannheim, Germany) according to the manufacturer's instructions. After overnight transfection, cells were treated with triphlorethol-A for $1 \mathrm{~h}$, and $1 \mathrm{mM}$ $\mathrm{H}_{2} \mathrm{O}_{2}$ was then added to the medium. After $24 \mathrm{~h}$, the cells were lysed with reporter lysis buffer (Promega, Madison, WI, USA). The lysate supernatant was then mixed with the luciferase assay reagent, and the mixture was placed in a luminometer to measure the light produced.

\subsection{Transient Transfection of Small Interfering RNA (siRNA)}

Cells were seeded to $60 \mathrm{~mm}$ cell culture dish at a density of $1.5 \times 10^{5}$ cells/mL and allowed to grow $70 \%$ confluency. Cells were transfected with $10 \mathrm{nM}$ of siControl (Santa Cruz, CA, USA) and $50 \mathrm{nM}$ of siRNA against OGG1 (Bioneer, Daejeon, Korea) by using Lipofectamine ${ }^{\mathrm{TM}} 2000$ (Invitrogen Inc., Carlsbad, CA, USA) based on the manufacturer's instructions. Twenty-four hours after transfection, 
cells were treated with triphlorethol-A for $1 \mathrm{~h}$, and $1 \mathrm{mM} \mathrm{H} \mathrm{H}_{2}$ was then added to the medium. After $24 \mathrm{~h}$, the cell viability was examined.

\subsection{Cell Viability}

Cells were seeded in a 96-well plate at a concentration of $1.0 \times 10^{4}$ cells/well and pretreated with $50 \mu \mathrm{M}$ of LY294002, $1 \mu \mathrm{M}$ of Akt inhibitor IV, or $1 \mu \mathrm{M}$ of U0126 for $1 \mathrm{~h}$, followed by treatment with $30 \mu \mathrm{M}$ of triphlorethol-A for $1 \mathrm{~h}$ and treatment with $1 \mathrm{mM} \mathrm{H}_{2} \mathrm{O}_{2}$ for $24 \mathrm{~h}$. MTT (50 $\mu \mathrm{L}$ of a $2 \mathrm{mg} / \mathrm{mL}$ stock solution) was then added to each well to yield a total reaction volume of $200 \mu \mathrm{L}$. After incubating for $4 \mathrm{~h}$, the plate was centrifuged at $1500 \mathrm{rpm}$ for $5 \mathrm{~min}$, and the supernatants were aspirated. The formazan crystals in each well were dissolved in $150 \mu \mathrm{L}$ dimethylsulfoxide, and the A540 was read on a scanning multi-well spectrophotometer [30].

\subsection{Statistical Analysis}

All values are represented as the mean \pm standard error (SE). The results were subjected to an analysis of variance (ANOVA) using Tukey's test for analysis of differences. Statistical significance was set at $p<0.05$.

\section{Discussion and Conclusions}

Oxidative stress reflects an imbalance between the systemic manifestation of ROS and the ability of a biological system to readily detoxify the reactive intermediates or to repair the resulting damage. Disturbances in the normal redox state of cells can cause toxic effects through the production of peroxides and free radicals that damage all components of the cell, including proteins, lipids, and DNA [31,32]. In particular, extreme oxidative stress can induce DNA base modifications such as 8-oxoG, which can generate DNA mutations and ultimately trigger apoptosis and various diseases [33,34]. During DNA synthesis, 8-oxoG forms a mismatched base pair with adenine, giving rise to a G:C-to-T:A transversion mutation, potentially altering gene function and resulting in cell death $[35,36]$. The modified base is removed by DNA glycosylase, and the lesion site subsequently undergoes repair processing by BER systems [37]. OGG1 acts as an 8-oxoG glycosylase and endonuclease during the BER process under conditions of oxidative stress [10,12]. The OGG1 gene is transcriptionally activated by Nrf2, which binds to ARE sequences in the OGG1 promoter [13,14]. Under non-stressed conditions, Nrf2 is anchored in the cytoplasm by binding to Keap1, which facilitates the ubiquitination and subsequent proteolysis of Nrf2 [15,38]. Thus, Keap1 negatively regulates Nrf2 both by enhancing its rate of proteasomal degradation and by altering its subcellular distribution. Upon activation, Nrf2 dissociates from Keap1, translocates into the nucleus, and heterodimerizes with other basic leucine-Zip transcription factors such as small Maf proteins, thereby increasing the transcription of ARE-driven genes [17]. Several mechanisms have been proposed for Nrf2-Keap1 dissociation and regulation of Nrf2 signaling [16]. Severe oxidative stress conditions induce cells to undergo cell death, which exposes surrounding tissues to the vicissitudes of the inflammatory immune response. Cell death may abolish various cellular signaling pathways, including anti-oxidative processes, such as the Nrf2 signaling pathway [39]. Our results presented here suggest 
that triphlorethol-A can suppress oxidative stresses and thereby protect cells against noxious stimuli, such as $\mathrm{H}_{2} \mathrm{O}_{2}$, formaldehyde, and ionizing radiation [21,22,24,40,41]. Upon exposure to various stress inducers, Nrf2 is released from Keap1 and translocates into the nucleus [42,43]. Nrf2-Keap1 dissociation and Nrf2 signaling are initiated by the phosphorylation of Nrf2 at serine 40 and specific threonine residues, as well as by the modification of cysteine residues in Keap1. Phosphorylation of Nrf2 is performed by various kinases, including mitogen-activated protein kinases, protein kinase C, PI3K/Akt, casein kinase-2, and PKR-like endoplasmic reticulum kinase [44]. In this study, we observed that inhibition of the Erk and PI3K/Akt pathways reduced the up-regulation of OGG1 expression by treatment with triphlorethol-A. Furthermore, these inhibitors suppressed the protective effects of triphlorethol-A against $\mathrm{H}_{2} \mathrm{O}_{2}$ treatment. Triphlorethol-A increased OGG1 expression via the Nrf2 signaling pathway, and thereby protected cells against the extreme oxidative stress induced by $\mathrm{H}_{2} \mathrm{O}_{2}$ treatment. Nrf2 signaling activation, via phosphorylation by Erk and Akt, was also induced by triphlorethol-A. Taken together, these data demonstrate that triphlorethol-A activates the BER system in response to oxidative stress, and thereby prevents DNA base modifications, mutations, and cell death induced by oxidative stress.

\section{Acknowledgments}

This work was funded by the Ministry of Education, Science \& Technology (MEST) of the Republic of Korea (NRF-2012R1A1A2005350).

\section{Author Contributions}

Ki Cheon Kim, In Kyung Lee, Kyoung Ah Kang, Mei Jing Piao, and Min Ju Ryu performed experimental works. Jeong Mi Kim collected Ecklonia cava and extracted with methanol, isolated and purified the compound. Nam Ho Lee analyzed NMR data to solve the structure of the compound. Ki Cheon Kim and Jin Won Hyun prepared experimental design and wrote the manuscript.

\section{Conflicts of Interest}

The authors declare no conflict of interest.

\section{References}

1. Saul, R.L.; Ames, B.N. Background levels of DNA damage in the population. Basic Life Sci. 1986, 38, 529-535.

2. Fortini, P.; Pascucci, B.; Parlanti, E.; D’Errico, M.; Simonelli, V.; Dogliotti, E. 8-Oxoguanine DNA damage: At the crossroad of alternative repair pathways. Mutat. Res. 2003, 531, 127-139.

3. Loft, S.; Fischer-Nielsen, A.; Jeding, I.B.; Vistisen, K.; Poulsen, H.E. 8-Hydroxydeoxyguanosine as a urinary biomarker of oxidative DNA damage. J. Toxicol. Environ. Health 1993, 40, 391-404.

4. Honda, M.; Yamada, Y.; Tomonaga, M.; Ichinose, H.; Kamihira, S. Correlation of urinary 8-hydroxy-2'-deoxyguanosine (8-OHdG), a biomarker of oxidative DNA damage, and clinical features of hematological disorders: A pilot study. Leuk. Res. 2000, 24, 461-468. 
5. Kikuchi, A.; Takeda, A.; Onodera, H.; Kimpara, T.; Hisanaga, K.; Sato, N.; Nunomura, A.; Castellani, R.J.; Perry, G.; Smith, M.A.; et al. Systemic increase of oxidative nucleic acid damage in Parkinson's Disease and multiple system atrophy. Neurobiol. Dis. 2002, 9, 244-248.

6. Matsui, M.; Nishigori, C.; Toyokuni, S.; Takada, J.; Akaboshi, M.; Ishikawa, M.; Imamura, S.; Miyachi, Y. The role of oxidative DNA damage in human arsenic carcinogenesis: Detection of 8-hydroxy-2'-deoxyguanosine in arsenic-related Bowen’s Disease. J. Invest. Dermatol. 1999, 113, 26-31.

7. Sato, S.; Mizuno, Y.; Hattori, N. Urinary 8-hydroxydeoxyguanosine levels as a biomarker for progression of Parkinson Disease. Neurology 2005, 64, 1081-1083.

8. Wu, L.L.; Chiou, C.C.; Chang, P.Y.; Wu, J.T. Urinary 8-OHdG: A marker of oxidative stress to DNA and a risk factor for cancer, atherosclerosis and diabetics. Clin. Chim. Acta 2004, 339, 1-9.

9. Boiteux, S.; O’Connor, T.R.; Lederer, F.; Gouyette, A.; Laval, J. Homogeneous Escherichia Coli FPG protein. A DNA glycosylase which excises imidazole ring-opened purines and nicks DNA at apurinic/apyrimidinic sites. J. Biol. Chem. 1990, 265, 3916-3922.

10. Krokan, H.E.; Nilsen, H.; Skorpen, F.; Otterlei, M.; Slupphaug, G. Base excision repair of DNA in mammalian cells. FEBS Lett. 2000, 476, 73-77.

11. Bogliolo, M.; Cappelli, E.; D'Osualdo, A.; Rossi, O.; Barbieri, O.; Kelley, M.R.; Frosina, G. Effect of S. Cerevisiae APN1 protein on mammalian DNA base excision repair. Anticancer Res. 2003, 23, 3727-3734.

12. de Souza-Pinto, N.C.; Eide, L.; Hogue, B.A.; Thybo, T.; Stevnsner, T.; Seeberg, E.; Klungland, A.; Bohr, V.A. Repair of 8-oxodeoxyguanosine lesions in mitochondrial DNA depends on the oxoguanine DNA glycosylase (OGG1) gene and 8-oxoguanine accumulates in the mitochondrial DNA of OGG1-defective mice. Cancer Res. 2001, 61, 5378-5381.

13. Dhénaut, A.; Boiteux, S.; Radicella, J.P. Characterization of the hOGG1 promoter and its expression during the cell cycle. Mutat. Res. 2000, 461, 109-118.

14. Ueta, E.; Sasabe, E.; Yang, Z.; Osaki, T.; Yamamoto, T. Enhancement of apoptotic damage of squamous cell carcinoma cells by inhibition of the mitochondrial DNA repairing system. Cancer Sci. 2008, 99, 2230-2237.

15. Keum, Y.S. Regulation of Nrf2-mediated phase II detoxification and anti-oxidant genes. Biomol. Ther. Seoul 2012, 20, 144-151.

16. Itoh, K.; Chiba, T.; Takahashi, S.; Ishii, T.; Igarashi, K.; Katoh, Y.; Oyake, T.; Hayashi, N.; Satoh, K.; Hatayama, I.; et al. An Nrf2/Small Maf heterodimer mediates the induction of phase II detoxifying enzyme genes through antioxidant response elements. Biochem. Biophys. Res. Commun. 1997, 236, 313-322.

17. Motohashi, H.; Katsuoka, F.; Engel, J.D.; Yamamoto, M. Small Maf proteins serve as transcriptional cofactors for keratinocyte differentiation in the Keap1-Nrf2 regulatory pathway. Proc. Natl. Acad. Sci. USA 2004, 101, 6379-6384.

18. Nakaso, K.; Yano, H.; Fukuhara, Y.; Takeshima, T.; Wada-Isoe, K.; Nakashima, K. PI3K is a key molecule in the Nrf2-mediated regulation of antioxidative proteins by hemin in human neuroblastoma cells. FEBS Lett. 2003, 546, 181-184. 
19. Wang, L.; Chen, Y.; Sternberg, P.; Cai, J. Essential roles of the PI3 Kinase/Akt pathway in regulating Nrf2-dependent antioxidant functions in the RPE. Invest. Ophthalmol. Vis. Sci. 2008, 49, 1671-1678.

20. Zipper, L.M.; Mulcahy, R.T. Erk Activation is required for Nrf2 nuclear localization during pyrrolidine dithiocarbamate induction of glutamate cysteine ligase modulatory gene expression in HepG2 cells. Toxicol. Sci. 2003, 73, 124-134.

21. Kang, K.A.; Lee, K.H.; Park, J.W.; Lee, N.H.; Na, H.K.; Surh, Y.J.; You, H.J.; Chung, M.H.; Hyun, J.W. Triphlorethol-A induces heme oxygenase-1 via activation of ERK and NF-E2 related factor 2 transcription factor. FEBS Lett. 2007, 581, 2000-2008.

22. Zhang, R.; Kang, K.A.; Piao, M.J.; Kim, K.C.; Lee, N.H.; You, H.J.; Hyun, J.W. Triphlorethol-A improves the non-homologous end joining and base-excision repair capacity impaired by formaldehyde. J. Toxicol. Environ. Health A 2011, 74, 811-821.

23. Piao, M.J.; Zhang, R.; Lee, N.H.; Hyun, J.W. Protective effect of triphlorethol-A against ultraviolet B-mediated damage of human keratinocytes. J. Photochem. Photobiol. B. 2012, 106, 74-80.

24. Kang, K.A.; Lee, K.H.; Chae, S.; Koh, Y.S.; Yoo, B.S.; Kim, J.H.; Ham, Y.M.; Baik, J.S.; Lee, N.H.; Hyun, J.W. Triphlorethol-A from Ecklonia Cava protects V79-4 lung fibroblast against hydrogen peroxide induced cell damage. Free Radic. Res. 2005, 39, 883-892.

25. Valavanidis, A.; Vlachogianni, T.; Fiotakis, C. 8-Hydroxy-2'-deoxyguanosine (8-ohdg): A critical biomarker of oxidative stress and carcinogenesis. J. Environ. Sci. Health. C. Environ. Carcinog. Ecotoxicol. Rev. 2009, 27, 120-139.

26. Struthers, L.; Patel, R.; Clark, J.; Thomas, S. Direct detection of 8-oxodeoxyguanosine and 8-oxoguanine by avidin and its analogues. Anal. Biochem. 1998, 255, $20-31$.

27. Mo, J.; Xia, Y.; Wade, T.J.; Schmitt, M.; Le, X.C.; Dang, R.; Mumford, J.L. Chronic arsenic exposure and oxidative stress: OGG1 expression and arsenic exposure, nail selenium, and skin hyperkeratosis in inner Mongolia. Environ. Health Perspect. 2006, 114, 835-841.

28. Sinha, D.; Biswas, J.; Bishayee, A. Nrf2-mediated redox signaling in arsenic carcinogenesis: A review. Arch. Toxicol. 2012, 87, 383-396.

29. Fukuyama, Y.; Kodama, M.; Miura, I.; Kinzyo, Z.; Kido, M.; Mori, H.; Nakayama, Y.; Takahashi, M. Structure of anti-plasmin inhibitor, eckol, isolated from the brown alga, Ecklonia kurome Okamura and inhibitory activities of its derivatives on plasma plasmin inhibitors. Chem. Pharm. Bull. 1989, 37, 349-353.

30. Carmichael, J.; DeGraff, W.G.; Gazdar, A.F.; Minna, J.D.; Mitchell, J.B. Evaluation of a tetrazolium-based semiautomated colorimetric assay: Assessment of chemosensitivity testing. Cancer Res. 1987, 47, 936-942.

31. Mena, S.; Ortega, A.; Estrela, J.M. Oxidative stress in environmental-induced carcinogenesis. Mutat. Res. 2009, 674, 36-44.

32. Thannickal, V.J.; Fanburg, B.L. Reactive oxygen species in cell signaling. Am. J. Physiol. Lung Cell. Mol. Physiol. 2000, 279, L1005-L1028.

33. Cooke, M.S.; Evans, M.D.; Dizdaroglu, M.; Lunec, J. Oxidative DNA damage: Mechanisms, mutation, and disease. FASEB J. 2003, 17, 1195-1214. 
34. Jackson, S.P.; Bartek, J. The DNA-damage response in human biology and disease. Nature 2009, 461, 1071-1078.

35. Hyun, J.W.; Choi, J.Y.; Zeng, H.H.; Lee, Y.S.; Kim, H.S.; Yoon, S.H.; Chung, M.H. Leukemic cell line, kg-1 has a functional loss of hOGG1 enzyme due to a point mutation and 8-hydroxydeoxyguanosine can kill KG-1. Oncogene 2000, 19, 4476-4479.

36. Hyun, J.W.; Jung, Y.C.; Kim, H.S.; Choi, E.Y.; Kim, J.E.; Yoon, B.H.; Yoon, S.H.; Lee, Y.S.; Choi, J.; You, H.J.; et al. 8-Hydroxydeoxyguanosine causes death of human leukemia cells deficient in 8-oxoguanine glycosylase 1 activity by inducing apoptosis. Mol. Cancer. Res. 2003, 1, 290-299.

37. Barzilai, A.; Yamamoto, K. DNA damage responses to oxidative stress. DNA Repair Amst. 2004, 3, 1109-1115.

38. McMahon, M.; Itoh, K.; Yamamoto, M.; Hayes, J.D. Keap1-dependent proteasomal degradation of transcription factor Nrf2 contributes to the negative regulation of antioxidant response element-driven gene expression. J. Biol. Chem. 2003, 278, 21592-21600.

39. Davies, K.J. Oxidative stress, antioxidant defenses, and damage removal, repair, and replacement systems. IUBMB Life 2000, 50, 279-289.

40. Kang, K.A.; Zhang, R.; Lee, K.H.; Chae, S.; Kim, B.J.; Kwak, Y.S.; Park, J.W.; Lee, N.H.; Hyun, J.W. Protective effect of triphlorethol-a from Ecklonia Cava against ionizing radiation in vitro. J. Radiat. Res. Tokyo 2006, 47, 61-68.

41. Zhang, R.; Lee, I.K.; Kang, K.A.; Piao, M.J.; Kim, K.C.; Kim, B.J.; Lee, N.H.; Choi, J.Y.; Choi, J.; Hyun, J.W. Cytoprotective effects of triphlorethol-A against formaldehyde-induced oxidative damage and apoptosis: Role of mitochondria-mediated caspase-dependent pathway. J. Toxicol. Environ. Health A 2010, 73, 1477-1489.

42. Kensler, T.W.; Wakabayashi, N.; Biswal, S. Cell survival responses to environmental stresses via the Keap1-Nrf2-ARE pathway. Annu. Rev. Pharmacol. Toxicol. 2007, 47, 89-116.

43. Sykiotis, G.P.; Bohmann, D. Stress-activated Cap'N'Collar transcription factors in aging and human disease. Sci. Signal. 2010, 3, re3.

44. Boutten, A.; Goven, D.; Artaud-Macari, E.; Boczkowski, J.; Bonay, M. Nrf2 targeting: A promising therapeutic strategy in chronic obstructive pulmonary disease. Trends Mol. Med. 2011, 17, 363-371.

(C) 2014 by the authors; licensee MDPI, Basel, Switzerland. This article is an open access article distributed under the terms and conditions of the Creative Commons Attribution license (http://creativecommons.org/licenses/by/4.0/). 